\title{
Understanding Social Media Use in Latin America
}

\section{Ryan Salzman ${ }^{1}$}

Recibido: 2015-01-23

Enviado a pares: 2015-01-26

DOI: 10.5294/pacla.2015.18.3.9
Aprobado por pares: 2015-03-26

Aceptado: 2015-04-06

Para citar este artículo / To reference this article / Para citar este artigo

Salzman R. (Septiembre de 2015). Understanding social media use in Latin America.

Palabra Clave, 18(3), 842-858. DOI: 10.5294/pacla.2015.18.3.9

\section{Abstract}

Social media use is increasingly popular worldwide. Yet little is known about what shapes social media use, particularly in developing regions of the world. This research project seeks to elucidate the determinants of social media use in eight contiguous Latin American countries from Mexico to Colombia using the Latin American Public Opinion Project 2012 survey data. Social media use for the purposes of advocating a political position is employed as the dependent variable with a series of individual-level characteristics included as independent variables. The results of the multinomial regression model explicates the determinants of social media use for gathering and/or disseminating political information as more able and interested individuals employ those media than their less able and/or interested counterparts. The results depart from prior research focused on general Internet use for news gathering as perceptions of the domestic new media industry do not impact social media use of this kind.

\section{Keywords}

Social Media, survey research (Source: Tesauro Unesco).

1 Northern Kentucky University, United States. salzmanr1@nku.edu 


\section{La comprensión del uso de los medios sociales en Latinoamérica}

\section{Resumen}

El uso de las redes sociales es cada vez más común en todo el mundo. Sin embargo, poco se sabe acerca de lo que conforma el uso de las redes sociales, especialmente en las regiones en desarrollo del mundo. Este proyecto de investigación tiene por objeto dilucidar los determinantes del uso de las redes sociales en ocho países de América Latina contiguos desde México hasta Colombia utilizando los datos de la encuesta de Opinión Pública Latinoamericana de Proyectos 2012. El uso de las redes sociales para efectos de defender una posición política se emplea como variable dependiente con una serie de características a nivel individual incluidas como variables independientes. Los resultados del modelo de regresión multinomial explican los determinantes del uso de las redes sociales para la recolección o difusión de la información política como individuos más capaces e interesados en emplear esos medios de comunicación que sus contrapartes menos capaces o interesados. Los resultados salen desde investigaciones previas que se centraron en el uso general de Internet para la recopilación de noticias, dado que la percepción de la nueva industria de medios de comunicación domésticos no afecta el uso de las redes sociales de este tipo.

\section{Palabras clave}

Redes sociales, investigación por encuestas (Fuente: Tesauro de la Unesco). 


\section{A compreensão do uso dos meios sociais na América Latina}

\section{Resumo}

O uso das redes sociais é cada vez mais comum em todo o mundo. Contudo, pouco se sabe sobre o que conforma o uso das redes sociais, especialmente nas regiões em desenvolvimento. Este projeto de pesquisa tem como objetivo esclarecer os determinantes do uso das redes sociais em oito países da América Latina contíguos desde o México até a Colômbia, utilizando dados da Pesquisa de Opinião Pública Latino-americana de Projetos 2012. O uso das redes sociais para efeitos de defesa de uma posição política se utiliza como variável dependente com uma série de características no âmbito individual incluídas como variáveis independentes. Os resultados do modelo de regressão multinomial explicam os determinantes do uso das redes sociais para a coleta e/ou difusão da informação política como indivíduos mais capazes e interessados em empregar esses meios de comunicação que suas contrapartes menos capazes e/ou interessadas. Os resultados são da pesquisa prévia que se centralizou no uso geral da internet para a recopilação de notícias como as percepções da nova indústria de meios de comunicação nacionais não afetam o uso das redes sociais desse tipo.

\section{Palavras-chave}

Redes sociais, pesquisa de opinião (Fonte: Tesauro da Unesco). 
Mass communication technology continues to penetrate all corners of the globe. Where there was none, there is now some. Where there was some, it is now ubiquitous. With the spreading of mass communication technology comes its adoption as the tool of choice for facilitating myriad behaviors (see Chafee, et al., 1978). Shopping, campaigning, communicating, and information gathering are just a few of the behaviors that have been fundamentally altered by advances in mass communication technology, specifically via the Internet. The primary goal of this study is to create an image of social media users in a set of contiguous Latin American states. These states are varied in their political and economic development, yet they share many historical and cultural similarities. This makes them ideal cases for comparison. To create that image, a set of demographic and political variables are employed using the systematic classification system identified by Salzman and Albarran (2011). Although this analysis is mostly basic, it is essential to engage before moving on to a deeper understanding of how social media affects various behaviors.

Social media are "a group of Internet-based applications ... that allow the creation and exchange of user-generated content" (Kaplan \& Haenlein, 2010, p. 61). Popular social media applications include Facebook, Twitter, YouTube, and LinkedIn. Social media are distinct from traditional media in many ways, but they are similar in their dissemination of information. Well over 150 million Latin Americans use social media applications that vary in their purpose and target audience (Simcot, 2014). One popular use for social media is news gathering (Anderson, 2014), with much of that news being political in nature. This project employs survey data that focuses specifically on political information.

Research in all contexts recognizes the popularity of social media and has begun the important task of relating that use to individual behaviors and attitudes (see for example de Zuniga, Jung \& Valenzuela, 2012), thus fitting into a larger understanding of how media affects people (Bartels, 1993). But despite this headlong push to uncover the effects of social media use, a deeper understanding of social media users remains absent. Instead, researchers and journalists lean on assumptions (i.e. social media users are 
younger) without discerning what actually determines social media use. The explication of social media use is the focus of this paper and should serve to inform future studies that consider the effects of social media use. ${ }^{2}$

\section{Who uses social media in Latin America?}

A decision to use media in general and social media specifically is reflective of the needs and desires of the individual and how that medium can fulfill those needs. That relationship is captured by the Uses and Gratifications Theory (U\&G) of media use. U\&G embraces the idea that individuals have social and psychological needs and that they perceive those needs as being best met by one media product over another (Cantril, 1942). ${ }^{3}$ In short, media serve distinct functions and individuals choose which media outlet or product to consume based on their desired gratification.

Like many theories, $\mathrm{U} \& \mathrm{G}$ requires that some assumptions about media consumption behavior be made (Wimmer \& Dominick, 1994). First, individuals initiate media selection. Second, audiences are active and their media behavior is goal-directed. Third, individual predispositions, social contact, and context produce expectations that guide media use. Understanding social media use among Latin Americans also requires an assumption that individuals initiate media selection. The assumption of consumer initiated behavior appears reasonable in today's media context where product options are numerous and technology enables decision making by the consumer. That technology and breadth of options also permits the assumption of active audiences. That there is an amalgamation of individual factors that work in concert to shape preferences and behaviors among individuals is not novel (see for example Lau, 2003). Thus, assuming that it is necessary to consider a broad array of factors influencing media consumption behavior is reasonable.

2 The political focus of the variables included in this study is an artifact of the best available data provided by a reliable source. Although this is a limitation of this research, the overall quality of the data moves our understanding of social media use forward with confidence.

3 Although the Uses and Gratifications approach to understanding media consumption fell into disfavor decades ago, it has experienced a kind of renaissance with the increased pluralism of media options in the Internet age. For an excellent discussion of Uses and Gratifications Theory and its evolution over time, see Ruggiero (2000). 
Although U\&G does not provide a streamlined theory for explaining decisions to employ social media, numerous factors are nonetheless in play and must be accounted for. ${ }^{4}$ Recent research looking at the determinants of news media consumption points to a systematic way of classifying those factors into categories (Salzman, 2011). ${ }^{5}$ Identifying broad categories for classification has many advantages for understanding behavior determinants. First, it provides greater generalizability as individual factors can vary under stable classifications. Second, classifying numerous factors under the simplified, theoretically based mechanisms that actually affect behavior allows for cleaner comparison. Third, as a result of that cleaner comparative reality, firmer conclusions about what shapes decisions to use social media can be drawn which can have greater predictive capability.

Employing data from 2008, Salzman (2011) and Salzman and Albarran (2011) examined news media consumption in Latin America utilizing three factor categories: ability, interest, and expectation. Those same three categories are applied in this study of social networking taken from 2012 survey data.

An individual's ability to use the Internet may be contingent on the amount of wealth possessed by that individual. Individuals with more wealth have greater ability to acquire the proper hardware (i.e. a computer) in order to use the Internet. Once that hardware is acquired, its operation requires a skill set that is dependent on the individual's level of education as operating a computer and navigating the Internet depend on literacy skills at least. Also, because of higher density of communications infrastructure, individuals in more metropolitan areas should have greater access to Internet services that allow them to use the Internet. Thus, individuals with greater wealth, education, and urban proximity should report higher levels of social media use in general as they are more "able".

4 For example, embracing the approach outlined by Uses and Gratifications Theory and combining it with media effects research, Windahl (1981) argued that media perceptions and expectations shape individual behavior, that motivation reflects interests, that there are alternatives to media, and that media content is important.

5 Researchers who apply U\&G often employ typologies to introduce some parsimony to what might otherwise be an unmanageable venture (see Finn, 1997; K.J. Anderson \& Revelle, 1995; Eysenck, 1991; McGuire, 1974). 
Ability Hypothesis: Individuals with greater ability will use social media more than individuals with less ability.

Individuals' use of social media can be shaped by their interest in current events as social media can be a tool for gathering (and disseminating) political information (see Stieglitz \& Dang-Xuan, 2012). Persons with greater political knowledge or political interest are likely to use social media to foster that interest/knowledge more than those with less of each. Interested individuals participate politically more than uninterested individuals (Norris, 2000). Thus, individuals who engage in various kinds of political behavior should be more likely to use social media as a tool for gathering political information and sharing political information as engaging in political behavior is a further indication of interest.

Interest Hypothesis: More interested individuals will utilize social media for gathering and sharing political information more than less interested individuals

The third dimension that may influence social media use for political purposes is the expectations that individuals hold. The clearest indication of an individual's media-related expectations in Latin America is the extent to which individuals trust the news media in their country. Prior research indicates that Internet news consumption serves as an alternative to traditional news media (Salzman, 2011). Whereas trust in news media may be expected to positively relate to consumption of traditional news media, individuals with less trust in the traditional domestic news media are expected to utilize the Internet and social media more to avoid news outlets they regard as untrustworthy. As the focus herein is understanding social media use for the purpose of gathering and sharing political information, it holds particularly true that individuals with less trust in the domestic news media will employ social media for information gathering purposes.

Expectation Hypothesis: Individuals with less trust in the domestic news media will report greater social media use for political information gathering and sharing than individuals with more trust in domestic news media 


\section{Research Design}

To test the hypotheses, this project identifies the impact of various demographic and political variables on the dependent variable, Social Network. The statistical analysis employs pooled cross-section data compiled from individual surveys administered in eight contiguous Latin American countries; Mexico, Guatemala, El Salvador, Honduras, Nicaragua, Costa Rica, Panama, and Colombia. The selection of these countries is based on the quality of comparison that is possible. They share many historical and cultural similarities with the deviation in democratic experience and economic development beginning only a few decades ago. The extent of shared characteristics should allow for better comparisons and contrasts of the statistical results.

The unit of analysis is the individual. When attempting to identify the attitudes and behaviors of individuals, few (if any) data gathering methods exceed the reliability, generalizability, and cost-effectiveness of surveys This project employs survey data from The Americas Barometer by the Latin American Public Opinion Project (LAPOP) 2012 dataset. ${ }^{6}$ While other forms of data rely on population aggregates that do not allow for inference based on individual characteristics, this study employs survey data with a large sample size that permits individual-level comparison of "all" individuals that is otherwise impossible. ${ }^{7}$ Besides their level of political activity and awareness, data were desired that did not exclude individuals living in more remote areas. As survey sampling is often subject to cost concerns, excluding rural populations is commonplace because it is much less expensive per interview than to include rural populations. The $2012 \mathrm{LAPOP}$ data set, however, includes all segments of the population - rural and urban, rich, middle class, and poor - so as to approximate a national probability sample. "Samples in each country were developed using a multi-stage probabilistic design” (LAPOP, 2012).

6 Thanks go to the Latin American Public Opinion Project (LAPOP) and its major supporters (the United States Agency for International Development, the United Nations Development Program, the Inter-American Development Bank, and Vanderbilt University) for making the data publicly available. www.LapopSurveys.org.

7 "All" individuals actually means voting age population. For example, although that age is 18 in Costa Rica, Nicaraguans can vote at 16 . Therefore, Nicaraguans are sampled at the ages of 16 and 17 whereas Costa Rican sampling begins at 18 . 
To increase the precision of the sampling results, the sample design employed the principle of "stratification" in its sampling method. Stratification involves dividing the target populations (Latin Americans) into basic units (i.e., the country) and subunits (i.e., regions within countries). These may be further stratified into sampling frames (such as clusters of households or blocks or neighborhoods). The sample of respondents is then selected from within each subunit in proportion to their overall share of the national population. Doing this ensures that no individuals from any area are automatically excluded from the study and that the samples taken are generalizable. Stratification encouraged respondent selection to be country, region, community, neighborhood, and household specific. Even when the household was selected, random interviewee selection within that household was encouraged by the use of the "next birthday" system. Once selected, interviews were conducted face-to-face by carefully trained interviewers. Anticipating the refusal of some respondents to cooperate, an estimate of non-coverage was included with a resulting oversample being drawn to compensate. The LAPOP data thus appears to adequately address those sampling concerns. ${ }^{8}$

The variables in this study are represented by single-item measures and multi-item variable indexes. The choice between single- and multiitem measures was dictated by the available survey data. Whenever possible, indexes constructed from multiple items are used to increase construct validity. While most of the survey responses were respondent self-identification, some others (i.e. city size) were completed by the survey administrator to ensure proper specification.

The dependent variable, Social Network, is a dichotomous variable that asks the survey respondent "in the last twelve months, have you read or shared political information through any social network website such as Twitter or Facebook or Orkut?" Answering "yes" results in a score of 1 and "no" responses are scored 0 . The dichotomous scoring mandates the use of a standard logistic regression model for those statistical analyses (Long \&

8 A detailed description of the survey sampling design can be found here: http://www.vanderbilt.edu/lapop/ ab2012/AB-2012-Tech-Info-12.18.12.pdf 
Freese, 2006). Standard errors are clustered per country. Respondents with missing data points are excluded from the pooled sample. Effect magnitudes are uninterpretable using that application alone.

Testing the Ability Hypothesis requires the inclusion of three variables; Education, Wealth, and Urban. The variable Education identifies the amount of education in years completed by the respondent and is scaled 0 to 18 . Wealth is a variable which is an additive measure of various items that the respondent may or may not own. These items include a television, refrigerator, land-line phone, cellular phone, vehicle (up to 3), washing machine, microwave, motorcycle, potable water in the house, bathroom in the house, computer, internet, and flat screen TV and are scored on a scale of 0 to $15 .{ }^{9}$ A respondent's score depends on the number of possessions that they claim. Urban identifies respondents living in an urban setting are scored 1 with nonurban dwellers receiving a score of 0 . This was identified by the survey administrator.

To test the Interest Hypothesis, five variables are employed. Political Interest is a single-item measure gauging respondent's interest in politics. It is scored 1-4 with 4 denoting high interest. Contact is an index of three questions asking if the respondent contacted various public officials in order to "solve a problem." Each question is dichotomous. The index is scaled 0-3. Vote is a single-item question that asked if the respondent voted in the last presidential election. A "yes" response is scored 1 and "no" is scored 0. Meeting is an index that measures meeting attendance for various groups and institutions. That multi-variable index is scaled 0-15. Protest is described above.

One variable is used to test the Expectation Hypothesis. Trust Media is a single-item measure that asks "to what extent do you trust the mass media?" This variable is scored 1-7 with 1 representing low trust and 7 representing high trust.

9 This measure is intended to replace the typical income question. This meliorates concerns of misreporting or refusal to report often associated with income questions. The use of household wealth also circumvents issues related to individuals such as family members who have no income of their own yet live a lifestyle reflective of the income of their family. For an example of a study that uses a similar measure, see The Legitimacy Puzzle in Latin America (Booth \& Seligson, 2009). 


\section{Table 1}

\section{Standard logistic model for "Social Network"}

\begin{tabular}{|c|c|c|}
\hline Independent Variable & Coef. & Standard error \\
\hline \multicolumn{3}{|l|}{ Ability } \\
\hline Education & $0.180^{* *}$ & 0.012 \\
\hline Wealth & $0.181^{* *}$ & 0.016 \\
\hline Urban & $0.432^{* *}$ & 0.105 \\
\hline \multicolumn{3}{|l|}{ Interest } \\
\hline Political Interest & $0.370^{* *}$ & 0.041 \\
\hline Contact & $0.251^{* *}$ & 0.056 \\
\hline Vote & -0.032 & 0.092 \\
\hline Meeting & $0.125^{* *}$ & 0.018 \\
\hline Protest & $0.187^{* *}$ & 0.032 \\
\hline \multicolumn{3}{|l|}{ Expectations } \\
\hline Trust Media & -0.042 & 0.024 \\
\hline Female & $-0.233^{* *}$ & 0.078 \\
\hline Age & $-0.046^{* *}$ & 0.004 \\
\hline Mexico - country dummy & 0.155 & 0.153 \\
\hline Guatemala - country dummy & $0.393^{*}$ & 0.161 \\
\hline El Salvador - country dummy & $0.736^{* *}$ & 0.159 \\
\hline Honduras - country dummy & $-0.401^{*}$ & 0.187 \\
\hline Nicaragua - country dummy & 0.080 & 0.183 \\
\hline Panama - country dummy & -0.228 & 0.166 \\
\hline Colombia - country dummy & 0.262 & 0.149 \\
\hline Constant & $-5.426^{* *}$ & 0.268 \\
\hline $\mathrm{N}$ & \multicolumn{2}{|c|}{11,536} \\
\hline Pseudo- $\mathrm{R}^{2}$ & \multicolumn{2}{|c|}{0.269} \\
\hline
\end{tabular}

${ }^{*} \mathrm{p}<.05 ;{ }^{* *} \mathrm{p}<.01$

Costa Rica is the excluded category to which the country dummies should be compared.

"Male" is the excluded category to which "female" should be compared.

It is axiomatic in social scientific research that some basic attributes of individuals can affect various individual-level preferences and behavior (see Almond \& Verba, 1963). For that reason some control variables are included that measure an individual's age, gender, and country of residence. Age is a count variable ranging from 15 to 89 . Female denotes the individuals' gender and is given a value of 1 for women and 0 for men. Lastly, 
the country of each respondent is identified via country dummy variables. In the analysis, Costa Rica is the excluded category.

\section{Results}

The results of the statistical analysis are presented in Table 1. The model appears to perform well with a strong pseudo- $\mathrm{R}^{2}$ value. The analysis focused on who uses social media finds strong support for the Ability Hypothesis and Interest Hypothesis with no evidence supporting the Expectation Hypothesis.

Employing the ability-interest-expectation typology informs our understanding of social media users. With a pseudo- $\mathrm{R}^{2}$ value of 0.269 , it is evident that the model is well specified, providing substantial explanatory value. Each of the ability measures is positively related to social media use in order to gather the dissemination of political information with strong statistical significance. This finding indicates the centrality of hardware and hard skills for social media use. Similar results were found in Salzman and Albarran's (2011) analysis of Internet use for news gathering in Latin America. Therefore, it should be assumed that Internet use of all kinds requires a set of financially and educationally determined abilities.

Interest is also related to social media use as political interest, contact, meeting, and protest are statistically significant with positively signed coefficients. The lack of statistical support for a vote-social media relationship is not too surprising as voting is a relatively simple political behavior that does not require special attention to inspire going to the polls. The strong results of the other interest measures illustrates the central role played by political interest in news consumption (Norris, 2000) and supports the contention that Latin Americans employ social media to satisfy the desire to gather information about politics.

The lack of support for the expectation hypothesis is somewhat unexpected as prior studies revealed a strong negative relationship between an individual's trust in the domestic media industry and using the Internet for news consumption (Salzman \& Albarran, 2011). The failure of the Trust Media variable to reach statistical significance likely indicates that social 
media use is not primarily considered a news source. This is an important distinction.

The control variables performed as expected. Older individuals use social media less than younger people. Women use social media less than men. Relative to Costa Ricans, only Guatemalans and El Salvadorans had significantly different social media behaviors. In both cases, individuals in those countries used social media more.

\section{Conclusion}

This study endeavored to understand social media use in eight Latin American countries; Mexico, Guatemala, Honduras, El Salvador, Nicaragua, Costa Rica, Panama, and Colombia. Rich survey data, taken from the LAPOP 2012 Americas Barometer, was employed to foster that understanding. The analysis focused on individual-level conditions, behaviors, and attitudes to try to understand what kind of Latin American uses social media to gather or disseminate political information. Many important conclusions can be drawn from the results.

Social media users in Latin America are wealthier, better educated, and more urban than their non-user counterparts. This finding was expected due to the nature of the devices required to engage social media. Computers and cell phones can be expensive and usually require some technology-related acumen to use properly. This comports with prior research that focused on Internet use more generally and for the purpose of gathering information (Salzman \& Albarran, 2011; Salzman, 2011). Regardless of the use, hardware and human capital are consistently part of the Internet-related behavior puzzle.

The results make clear that social media is another tool for individuals who are interested in politics to foster that interest. This is in line with prior research that found interest and media use of various types related to interest in politics (Stieglitz \& Dang-Xuan, 2012; Norris, 2000). It is notable that social media use appears related to less-traditional political participa- 
tion; attending meetings of civic groups and protesting. This relationship appears to fit neatly with the presumption that social media users are younger and more interested in nontraditional engagement.

The extent to which social media users trust the domestic media does not factor into using social media. This finding is a significant departure from prior research on news gathering via the Internet where individuals skeptical of domestic news outlets sought information from online sources (Salzman, 2011). Like the findings related to fostering interest in politics, it was hypothesized that individuals with less trust in the domestic news media would similarly employ social media more for political purposes. This was not the case, illustrating a significant difference between Internet use in general and social media use in particular. That distinction will be essential for future research to embrace in theory building as well as in statistical model applications.

In short, individuals who use social media for gathering and/or disseminating political info are more able and interested, but appear unaffected by their expectations of traditional domestic media. This is similar to research that considered Internet use for news consumption, but the differences indicate that social media use is not the same as consuming more traditional news. Latin Americans use social media because they are able and it gratifies their desire to gather some information. But they are not using it to avoid domestic news products.

Reflecting on the findings of this project two additional considerations come to mind. The first has to do with "ability" trends in the future. While literacy will remain necessary for Internet media use, the connection with wealth may decline in the coming decades as tools for accessing the Internet (i.e. cell phones) become more affordable and available. As the population of users expands, the implications of this research may also be altered.

The relationship of interest to social media use is important and may be generalized. This project looked at political interest and social media use for political purposes. These findings could indicate that interest in other 
things may also relate to social media use to satisfy that interest. For example, an individual who is interested in sports may therefore be expected to use social media for sports-related purposes. Likewise, a person who is interested in a specific product or service (i.e. gluten-free foods and cooking) will use social media to foster that interest. This is an important finding as it indicates a much broader and deeper implication for understanding social media use of all kinds. The same is true for the sample of countries as assumptions about the entire region can be derived from this research. Thus, although this project is limited to the best available social media-related survey data in eight contiguous and comparable countries in Latin America, the knowledge gained should inform social media research of all kinds in all of Latin America.

\section{Bibliography}

Almond, G. A. \& Verba, S (1963). The Civic Culture: Political Attitudes and Democracy in Five Nations. Boston, MA: Princeton University Press.

Anderson, K.J. \& Revelle, W. (1995). Personality processes. Annual Review of Psychology, 46, 295-328.

Anderson, M. \& Caumont, A. (2014). How social media is reshaping news. Pew Research Center. www/pewresearch.org/facttank/2014/09/24/how-social-media-is-reshaping-news/ (Date of reference: October 29, 2013).

Bartels, L. M. (1993). Messages received: The political impact of media exposure. American Political Science Review, 87(2), 267-285.

Booth, J. A. \& Seligson, M. A. (2009). The legitimacy puzzle in Latin America: Political support and democracy in eight nations. New York: Cambridge University Press.

Cantril, H. (1942). Professor quiz: A gratifications study. In P.F. Lazarsfeld \& F. Statnton (Eds.), Radio research 1941 (pp. 34-45). New York: Duell, Sloan \& Pearce. 
Chafee, S., Katzman, N., McCombs, M., Roberts, D. \& Comstock, G. (1978). Television and Human Behavior. New York: Columbia University Press.

de Zúñiga, H. G., Jung, N. \& Valenzuela, S. (2012). Social media use for news and individuals' social capital, civic engagement and political participation. Journal of Computer-Mediated Communication, 17(3), 319-336.

Eysenck, H. J. (1991). Dimensions of personality: 16, 5, or 3? - Criteria for a taxonomic paradigm. Personality and Individual Differences, 12, 773-390.

Kaplan A. M. \& Haenlein M. (2010). Users of the world, unite! The challenges and opportunities of social media. Business Horizons, 53(1).

LAPOP. (2012). “AmericasBarometer: Sample Design.” Latin American Public Opinion Project. http://www.vanderbilt.edu/lapop/ab2012/AB2012-Tech-Info-12.18.12.pdf(Date of reference: October 29, 2013).

Lau, R. R. (2003). Models of decision-making. In D. O. Sears, L. Huddy \& R. Jervis (eds.), Oxford handbook of political psychology. New York: Oxford University Press.

Long, J. S. \& Freese, J. (2006). Regression Models for Categorical and Dependent Variables Using Stata ( $2^{\text {nd }}$ ed. $)$. College Station, TX: StataCorp LP.

McGuire, W. J. (1974). Psychology motives and communication gratifications. In J.G. Blumler \& E. Katz (Eds.), The uses of mass communications: Current perspectives on gratifications research ( $\mathrm{pp}$. 167-196). Beverly Hills, CA: Sage.

Norris, P. (2000). A virtuous circle: Political communications in postindustrial societies. New York: Cambridge University Press. 
Salzman, R. (2011). News media consumption in Latin America: Who does It? Journal of Spanish Language Media, 4, 23-39.

Salzman, R. \& Albarran, A B. (2011). Internet use in Latin America. Palabra Clave, 14(2), 297-313.

Simcot, R. (2014). "Social media fast facts: Latin America." eModeration blog. http://www.emoderation.com/social-media-fast-facts-latinamerica/ (Date of reference: October 29, 2013).

Stieglitz,S. \& Dang-Xuan,L. (2013).Social media and political communication:A social media analytics framework. Social Network Analysis and Mining, 3(4), 1277-1291.

Wimmer, R. D. \& Dominick, J. R. (1994). Mass media research: An introduction. Belmont, CA: Wadsworth.

Windahl, S. (1981). Uses and gratifications at the crossroads. Mass Communication Review Yearbook, 2, 174-185. 